E. Lunarska ${ }^{1}$, A. Polanskiy ${ }^{2}$

${ }^{1}$ Institute of Physical Chemistry, Polish Academy of Sciences, Kasprzaka 42, 01-224 Warsaw, Poland

${ }^{2}$ R\&D Company Electronic \& Beam Technologies Ltd., St. Petersburg, Russia

\title{
KINETIC MEASUREMENTS OF HYDROGEN DISTRIBUTION BETWEEN DIFFERENT STATES IN EXPLOITED STEELS
}

\begin{abstract}
The Hydrogen Analyzer AV-1 equipped with the high resolution registration system has been used to measure the kinetics of hydrogen extraction and thus to distinguish the different states of hydrogen in metals. The hydrogen distribution between the various energetic states as measured in the pipe line ferrite-pearlite steels being in service for different time has been shown to depend on conditions and on time of exploitation. Results of such measurements may be used for assessing the life time of industrial installations.
\end{abstract}

Key words: hydrogen kinetic and static vacuum extraction, hydrogen trapping, ferrite-pearlite pipe line steels

\section{INTRODUCTION}

Hydrogen content in metals has been generally measured at its desorption from specimens heated in vacuum (vacuum extraction) or in nitrogen flux (Leco method). In both cases the total content of hydrogen in the metal has been mostly evaluated. The specially designed Hydrogen Analyzer $\mathrm{AV}-1^{\circledR}$ equipped with the high-sensitive magnetic mass spectrometer tuned to record hydrogen and with the digital recording and processing systems allows the precise measurement of hydrogen escaping from the samples and thus to record the kinetic of hydrogen extraction. The minimum recordable hydrogen flux $\left(8 \times 10^{-9} \mathrm{~m}^{3} \mathrm{~Pa} / \mathrm{s}\right)$ corresponds to sensitivity of measurements less than $0.01 \mathrm{ppm}$ of hydrogen with the error under $3 \%$ [1].

The recorded hydrogen extraction curves reveal several maxima (Fig. 1). Each maximum corresponds to the escaped portion of hydrogen bound in metal with different binding energy (different trapping efficiency). Under some conditions, not only the amount of hydrogen bound with specific traps but also the binding energy with those traps can be calculated $[2,3]$. 


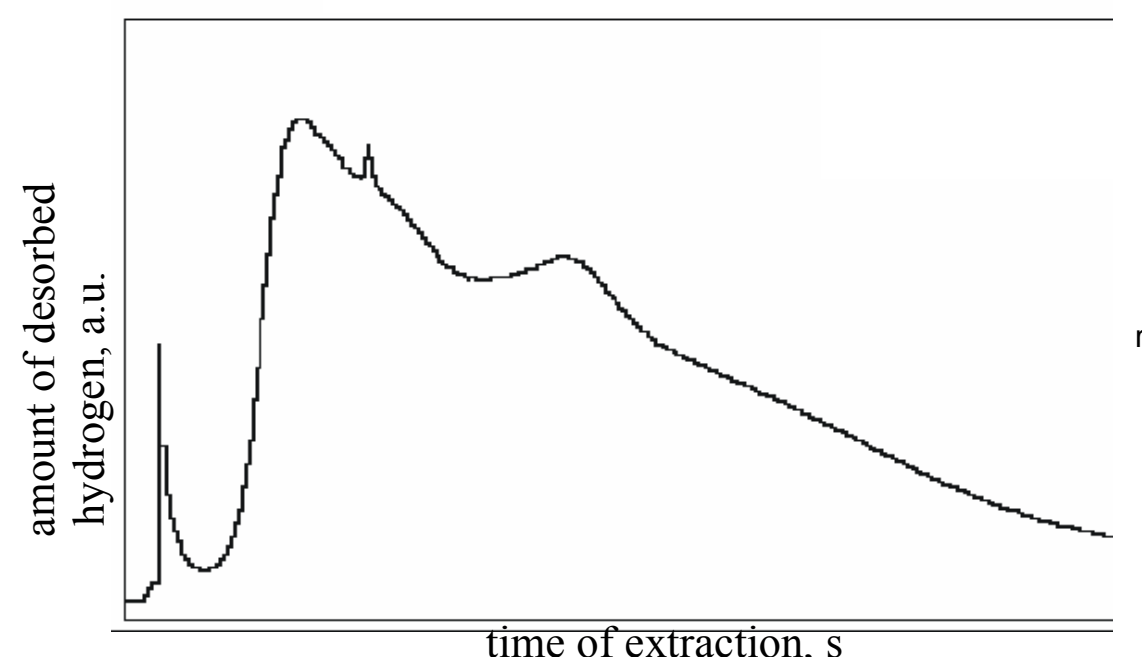

Fig. 1. Example of kinetic hydrogen extraction curve (amount of escaped hydrogen vs. time of heating at constant temperature) recorded in AV-1 analyzer for steel heated at $530^{\circ} \mathrm{C}$ for $30 \mathrm{~min}$

The absorption of hydrogen evolving in corrosion of ferrite-pearlite steels of the oil and gas pipe lines leads to the change of the steels structure [4]. As a result, in the course of exploitation, the hydrogen trapping efficiency of steel and thus, the hydrogen distribution between the different traps have been modified [5 - 7]. Since the state of hydrogen in metal (diffusible, bound to traps of various binding energy) affects the plasticity loss, the knowledge of hydrogen distribution may be used for evaluation the level of the steel degradation. In the case of fatigue tested Al specimen and thermomechanical cycled Ti tube the metal cracking has been shown to be proceeded by the hydrogen redistribution between the traps: the hydrogen occupancy of the low energy sites close to the crack was much higher than that in the metal apart from the crack [2, 3].

In present work the hydrogen distribution between the various energetic states in ferrite-pearlite steels exploited in different pipelines as measured by the kinetic vacuum extraction, has been evaluated and discussed.

\section{MATERIALS AND EXPERIMENTAL PROCEEDURE}

The ferrite-pearlite steel $(0.1 \% \mathrm{C}, 1-2 \% \mathrm{Cr}, 1 \% \mathrm{Mn}$ type) from two pipes (A and $\mathrm{B}$ ) exploited for different time and as received steel $\mathrm{A}$ were studied. In the case of both pipes the deposited sour water caused the corrosion of the inside bottom surface (site 2 , Fig. 2).

The sites of the specimens cutting from pipes is shown in Fig. 2. In order to evaluate the differently bound hydrogen more precisely, the following procedure was applied to each sample:

- fast (several seconds) heating to $530^{\circ} \mathrm{C}$ and keeping for about $1600 \mathrm{~s}$;

- second fast heating to $750^{\circ} \mathrm{C}$ without opening the apparatus $\mathrm{C}$ for about $3000 \mathrm{~s}$;

- third fast heating to $850^{\circ} \mathrm{C}$ without opening the apparatus for about $3000 \mathrm{~s}$.

During each step, the amount of escaped hydrogen was recorded. For comparison, the hydrogen extraction was also done at $600^{\circ} \mathrm{C}$ in apparatus where escaped hydrogen has been permeated through the Pd filter (static extraction). The obtained results of 
extraction were compared with the evaluated and described elsewhere [5-8] state of the material degradation of studied pipes.

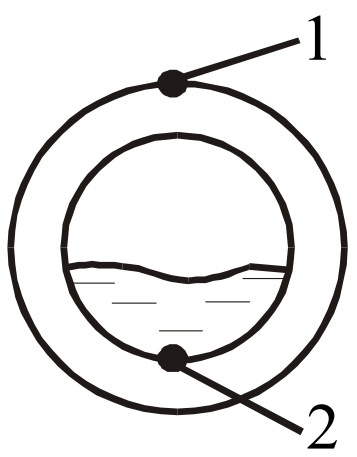

Fig. 2. Scheme

of the sites

of the specimens cutting

from the pipes

\section{RESULTS AND DISCUSSION}

The examples of the hydrogen desorption spectra recorded at different temperature for the same specimen, are shown in Fig. 3. The areas under the peaks correspond to the amount of hydrogen desorbed at given temperature. It is seen that some amount of hydrogen has been escaped from the material at its heating to higher temperature.

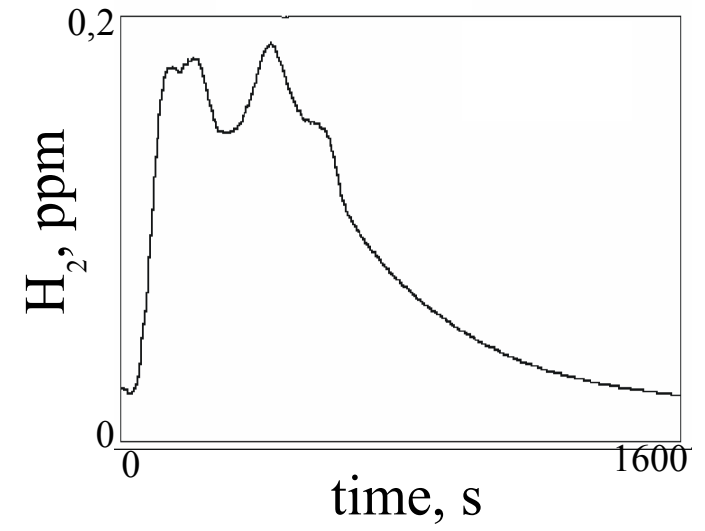

a

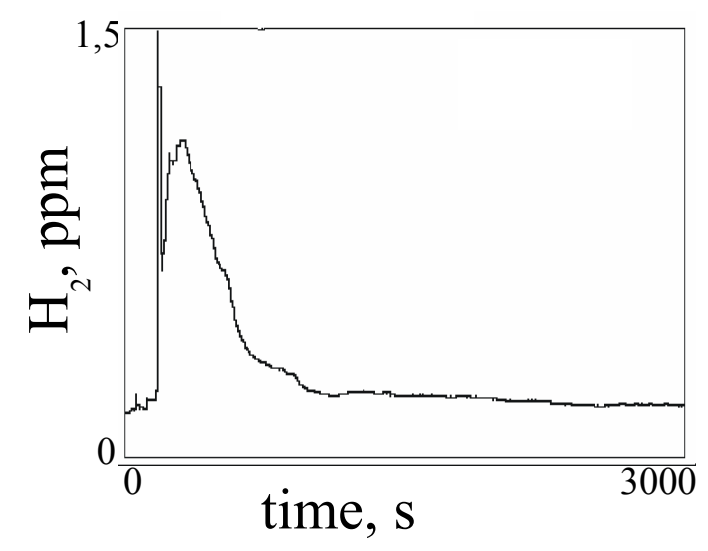

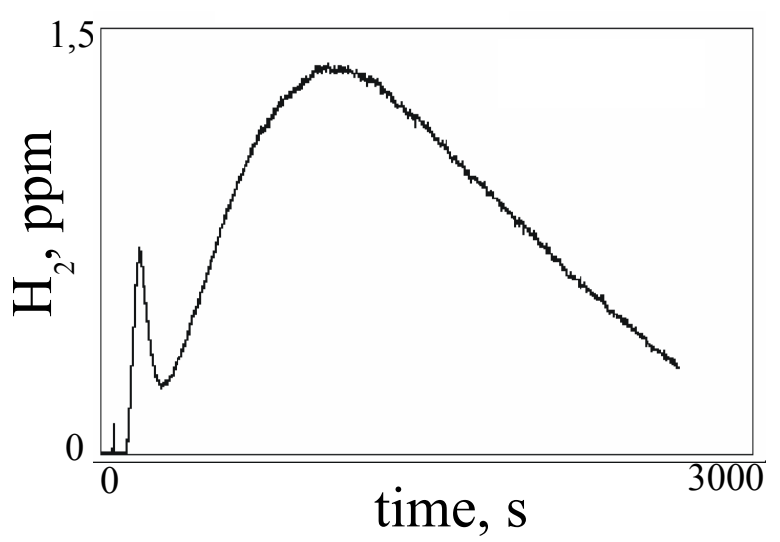

b

Fig. 3. Hydrogen desorption from one specimen: (a) $530^{\circ} \mathrm{C}$; (b) $750^{\circ} \mathrm{C}$; (c) $850^{\circ} \mathrm{C}$

The areas of deconvoluted peaks for specimens 1 and 2 of pipe B are presented in Fig. 4. From specimen B-2 the much higher amount of hydrogen escaped at longer 
heating than from specimen B-1, revealing that the higher amount of hydrogen has been accumulated in deep traps in specimen B-2 than in specimen B-1 [2, 3].

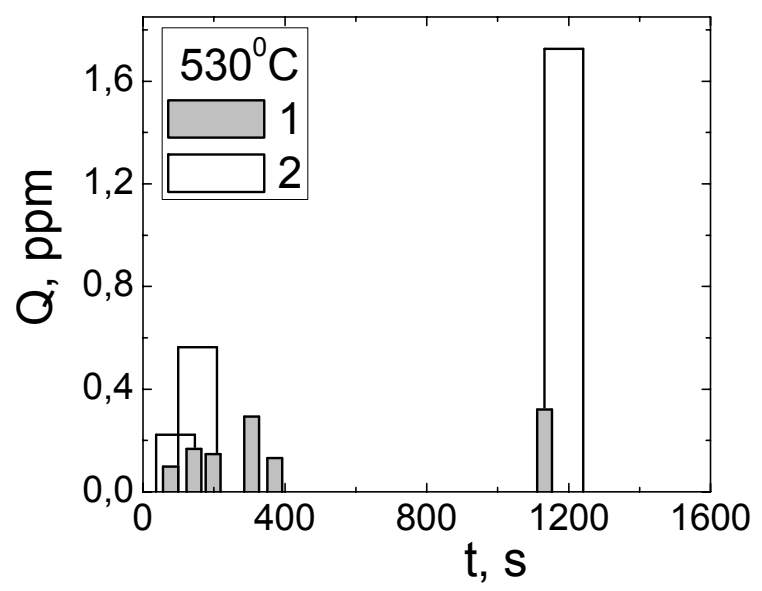

Fig. 4. The amount of hydrogen escaped from specimens 1 and 2 (Fig. 2) of pipe $B$ during the measurements at $530^{\circ} \mathrm{C}$

Fig. 5. shows the amount of hydrogen escaped at different temperature from specimens A and A-2. From as received material almost all hydrogen escaped at $530^{\circ}$; amount of hydrogen desorbed at $750^{\circ} \mathrm{C}$ was small (Figs. 5a and 5c). From material being in service (A-2), the hydrogen mostly escaped at heating to $750^{\circ} \mathrm{C}$ and only small amount escaped at $530^{\circ} \mathrm{C}$ (Figs $5 \mathrm{~b}$ and $5 \mathrm{~d}$ ). Hydrogen content desorbed at $850^{\circ} \mathrm{C}$ was negligible for all specimens (Fig. 6).

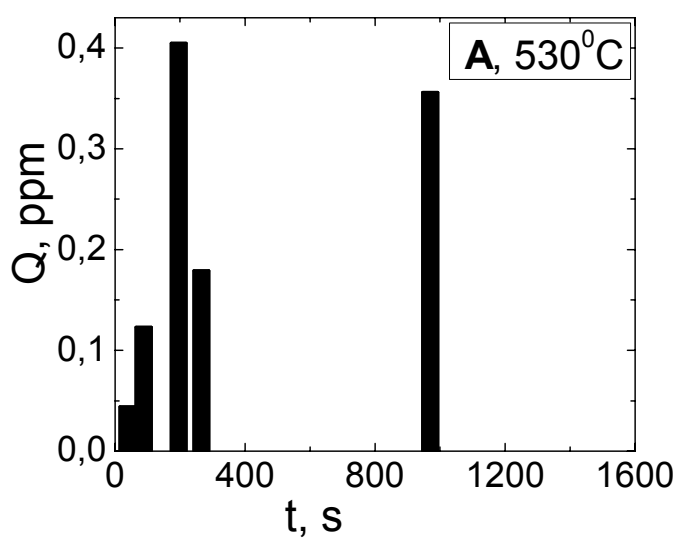

a

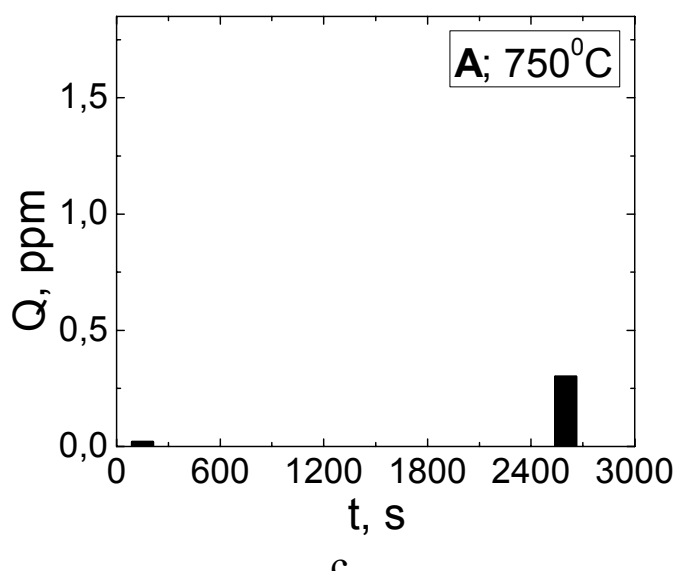

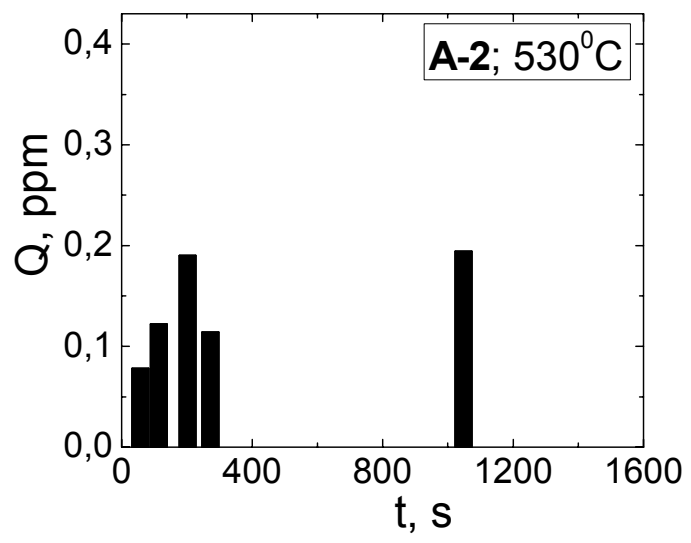

b

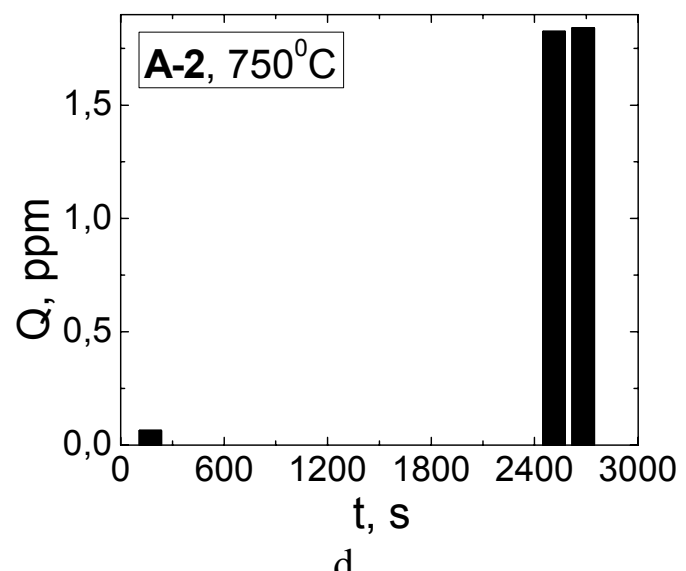

Fig. 5. The amount of hydrogen escaped from steel A during the measurements at different temperature; (a), (c) - as received material A, (b) (d) - specimen A-2; (a) (b) $-530^{\circ} \mathrm{C}$; (c) (d) $-750^{\circ} \mathrm{C}$ 


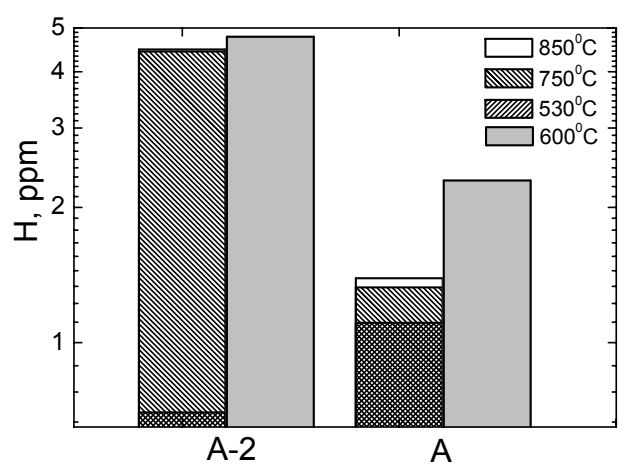

Fig. 6. The amount of hydrogen escaped at different temperature in the case of kinetic desorption and during the measurements at constant temperature $\left(600^{\circ} \mathrm{C}\right)$

As seen in Fig. 6, the total hydrogen amount recorded at kinetic measurements is quite similar to that measured at static extraction at $600^{\circ} \mathrm{C}$. However, in the first case not only the total hydrogen content but also its distribution between the traps can be evaluated

From presented results it follows that in the course of the pipe line exploitation, the ratio of deeply trapped hydrogen to the total hydrogen content increased (Figs. 5, 6). This might be associated with the stated earlier change of the ferrite lattice parameters $[5,6]$ and increase in the hydrogen trapping efficiency $[6,7]$ of the exploited material in comparison with as received one. The hydrogen distribution has been found also to depend on exploitation conditions (Fig. 4): the higher ratio of deeply trapped hydrogen occurred in exposed to the aggressive medium material of site 2 (Fig. 2). It should be noted that during exploitation of pipeline steels their mechanical properties decreased $[5,6]$ and susceptibility to hydrogen induced blistering increased [7]. Especially pronounced degradation revealed material of site 2 [5-8]. Therefore, the hydrogen accumulation in deep traps presumably assisted the material deterioration during the pipe exploitation. By kinetic hydrogen extraction the level of material degradation may be evaluated.

The above results seem to contradict the data [2, 3] showing the high hydrogen occupancy of the low energy sites, close to the cracks. However in present studies, the hydrogen distribution has been measured in the steel not subjected to straining. At the active straining (including the mechanical and thermo-mechanical tests) deeply trapped hydrogen present in the metal might be liberated and assisted the metal cracking. The studies of the effect of straining on the hydrogen distribution between the traps and being in progress may deliver the information for deeper understanding of hydrogen assisted cracking.

\section{CONCLUSIONS}

1. Kinetic measurements of hydrogen extraction by Hydrogen Analyzer AV-1 allow evaluation the hydrogen distribution between the various energetic states in metal.

2. Hydrogen distribution among the traps in the pipe line ferrite-pearlite steels depend on the conditions and time of exploitation. Increased ratio of deeply trapped hydrogen corresponds to the decrease in mechanical properties of material in service. 
3. The kinetic measurements may be used for prediction of the installations life time.

\section{REFERENCES}

1. Hydrogen Analyzer AV-1, Engineering Specification \# 0214, "RDC Electron \& Beam Technology" LtD, St.Peterburg, Russia.

2. Polyanskiy A.M., Polanskiy V.A., Popov-Diumin D.B.: "The use of the analyzer AV-1 for studyin $\mathrm{g}$ dynamics of hifg-temperature vacuum extraction of hydrogen from metallic probes. Materialovedenie, 98 (2005) 51-54.

3. Polyanskiy A.M., Polyanskiy V.A., Kozlov E.A.: "Konversija zaselennych energeticheskich sostojanij vodoroda $\mathrm{V}$ konstrukcionnych materialach pri termomechanioczeskom nagruzenii i razrusheni". Proc. III Rus. Conf. „Fiziczeskie problemy wodorodnoj energetyki”, St.Petrerburg, Joffe Phystechnical Institute (2006) 110-113.

4. Zagórski A., Spychalski W., Matysiak H., Majdan W., Słobodyan Z., Łunarska E.,Nykyforchyn H., Kurzydłowski K. J.: „Degradacja materiałów rurociagów ropy naftowej spowodowana korozja i nawodorowaniem", Proc.VII Conf. „Zarządzanie ryzykiem w eksploatacji rurociągów”, Centrum Diagnostyki Rurociagów, Płock (2004) 135-141.

5. Slobodyan. D, Lunarska E., Petrushchak O., Nykyforchyn H.: "Pecularities of corrosion fracture inner side surface of oil pipeline" Phys. Mechanics of Materials, 38 (2002) 783-785.

6. Nykyforchyn H., Slobodyan D., Petrushchak O., Łunarska E.: "Rola wodoru w korozyjnym niszczeniu wewnętrznych powierzchni rurociagu naftowego", Ochrona przed Korozją, 45 (2002) 445-459.

7. Lunarska E., Nikiforow K., Nykyforchyn H.: "Study of the metal degradation by hydrogen permeation method" Proc. $2^{\text {nd }}$ Intern Conf. Environmental Degradation of Engineering Materials, EDEM-2003, 264 Event of EFC, Bordeaux, 2003, CD PH2.

8. Lunarska E., Nykyforczyn H.: unpublished results (2002 - 2006). 